\title{
Ísetning á kera við gallblöðrubólgu á Landspítala 2010-2016
}

\section{Katrín Hjaltadóttir ${ }^{1}$ \\ Kristín Huld Haraldsdóttir ${ }^{1,3}$ \\ Pétur Hörður Hannesson ${ }^{2,3}$ \\ Páll Helgi Möller ${ }^{1,3}$}

Höfundar eru öll læknar.

'Skurðdeild, ${ }^{2}$ röntgendeild Landspítala, ${ }^{3} æ k$ nadeild Háskóla Íslands.

Fyrirspurnum svarar Katrín Hjaltadóttir, katrinhjalta@gmail.com

\section{Inngangur}

Bráð gallblöðrubólga er ein algengasta innlagnarástæðan á kviðarholsskurðdeildir og stór hluti sjúklinganna eru aldraðir. ${ }^{1}$ Alpjóðlegar leiðbeiningar um meðferð bráðrar gallblöðrubólgu hafa nýlega verið endurskoðaðar. ${ }^{2}$ Samkvæmt peim er mælt með að meta umfang bólgu, meðal annars með myndgreiningarrannsókn og ákvarða meðferð í samræmi við pað. Mælt er með aðgerð hjá sjúklingum sem hafa væg bólgumerki og með tímalengd einkenna innan við 7 daga hjá reynslumiklum skurðlæknum en að öðrum kosti skal miða við 72 klukkustundir.

Aðgerðin er yfirleitt gerð í kviðsjárspeglun (laparoscopy) en stundum er ekki talið öruggt eða mögulegt að framkvæma aðgerðina í kviðsjá og henni pví breytt í opna aðgerð. Rannsóknir hafa sýnt að hlutfall pess að gallblöðrutöku í kviðsjá sé breytt í opna aðgerð sé um $5 \%{ }^{3}$

Gallblöðrutaka í kviðsjá er í flestum tilvikum örugg með dánartíðni undir 0,8\%. Bráðaaðgerð fylgir pó aukin áhætta fyrir sjúklinginn, bæði hjá peim sem teljast frískir en einnig hjá öldruðum og peim sem hafa undirliggjandi fylgisjúkdóma (comorbidity), en rannsóknir hafa sýnt fram á að dánartíðni er mun hærri en við valaðgerð, eða 14-30\%., ${ }^{4,5}$ Erlendar rannsóknir, bæði frá Evrópu og Bandaríkjum Norður-Ameríku, sýna að um helmingur sjúklinga sem leggjast inn með bráða gallblöðrubólgu er meðhöndlaður með íhaldssamri meðferð (concervative treatment) prátt fyrir að ráðlögð meðferð sé gallblöðrutaka., Ástæður fyrir peirri ákvörðun geta verið margvíslegar en hún er venjulega í höndum vakthafandi skurðlæknis. Hún byggist meðal annars á undirliggjandi ástandi sjúklings ásamt fylgisjúkdómum, aðgengi að skurðstofu, reynslu og tímalengd einkenna, svo eitthvað sé nefnt.

\begin{abstract}
Á G R I P
Inngangur

Bráð gallblöðrubólga er ein algengasta ástæða bráđainnlagnar á kviðarholsskurðdeild. Meðferðin er gallblöðrutaka en pegar aðgerð er ekki talin fýsileg er gefin íhaldssöm meðferð með sýklalyfjum. Svari sjúklingur ekki meðferð er lagður keri i gallblöđru gegnum húð. Markmið rannsóknarinnar var að skoða ísetningu gallblöðrukera og fylgikvilla peirrar meðferðar á Landspítala.
\end{abstract}

\section{Efniviður og aðferðir}

Afturskyggn rannsókn. Farið var í gegnum sjúkraskrár allra með sjúkdómsgreiningar K80-85 árin 2010-2016 og breytur skráđar í Excel sem einnig var notað við úrvinnslu. Notuð var lýsandi tölfræði.

\section{Niðurstöður}

Alls fengu 4423 sjúklingar galltengdar sjúkdómsgreiningar á tímabilinu. Par af voru 1255 (28\%) með bráða gallblöðrubólgu og meðalaldur peirra 58 ár (bil: 18-99). Alls fengu 88 (14\%) gallblöðrukera og var meðalaldur peirra 71 ár (bil: 28-92). Hjá 62 (70\%) var kerinn lagður í gegnum lifur. Meðaltímalengd kera var 12 dagar (bil: 0-87). Gerð var gallvegamyndataka um kerann hjá 71 sjúklingi. Sautján sjúklingar voru útskrifaðir heim meơ kera. Helmingur sjúklinga $(n=45,51 \%)$ fór síðar í gallblöðrutöku í kviðsjá, að meðaltali 101 degi frá keraísetningu (bil: 30-258). Breytt var í opna aðgerð hjá 5 sjúklingum (12\%). Međalaðgerðartími kviðsjáraðgerða var 96 mínútur. Tuttugu og sjö sjúklingar (31\%) fengu 28 fylgikvilla og voru flestir minniháttar. Algengasti fylgikvillinn var að keri dróst út $(n=20)$ en aðrir voru gallleki $(n=3)$, verkir $(n=3)$ og endurtekin gallblöorubólga $(n=2)$. Fimm sjúklingar $(6 \%)$ létust innan 30 daga frá keraísetningu, prír vegna sýklasóttarlosts en tveir af ástæðum ótengdum sjúkdómnum eða meðferðinni.

\section{Ályktun \\ Ísetning gallblöðrukera er ekki algeng meðferð við bráðri gallblöðru- bólgu á Landspítala. Meðferðin er örugg og getur gagnast vel eldri} sjúklingum sem ekki er treyst í skurðaðgerð.

https://doi.org/10.17992//bl.2019.04.226

Pegar ákvörðun er tekin um íhaldssama meðferð er sjúklingur meðhöndlaður með sýklalyfjum en auk pess er mögulegt að leggja kera gegnum húð og inn í gallblöðruna (percutaneous cholecystostomy) til að létta á henni. Aðferðinni var fyrst lýst sem meðferð við bráðri gallblöðrubólgu af Radder árið 1980 pótt að tæknin hafi verið til staðar frá pví 1921. ${ }^{6}$ Síðan pá hefur gallblöðrukeri verið valkostur við meðferð bráðrar gallblöðrubólgu hjá bráðveikum sjúklingum eða peim sem eru í aukinni áhættu á fylgikvillum tengdum svæfingu og aðgerð. Pessari meðferð er stundum beitt ef sjúklingar eru óstöðugir eða svara ekki hefðbundinni meðferð með sýklalyfjum. Samhliða eru sjúklingum gefin sýklalyf í æð. 
Gallblöðrutaka er framkvæmd 6-8 vikum síðar ef ábending er fyrir pví og sjúklingur talinn pola valaðgerð.,7,8

Samkvæmt nýju meðferðarleiðbeiningunum er nú mælt með að setja gallblöðrukera fljótt eftir greiningu hjá peim sem eru með umtalsverða bólgu og/eða er ekki treyst í skurðaðgerð. ${ }^{2}$ Gallblöðrukeri er oftast lagður í staðdeyfingu með aðstoð ómunar eða tölvusneiðmyndar og er inngripið oftast framkvæmt af sérfræðilækni á röntgendeild. ${ }^{9}$ Mikilvægt er að leggja kerann gegnum lifur (transhepatic), séu ekki frábendingar fyrir pví, til að fyrirbyggja gallleka frá gallblöðru pegar kemur að pví að fjarlægja kerann. Engar algerar frábendingar finnast fyrir inngripinu en sem dæmi um frábendingar fyrir pví að leggja kera um lifur er meðferð með blóðpynningarlyfjum, storkukvillar (coagulopathy) eða vökvasöfnun í kvið (ascites). ${ }^{10-13}$ Inngripið tekst í um 97\% tilvika og er dánartíðni við meðferðina lág (0-4\%). ${ }^{9}$ Fylgikvillar af inngripinu og pví að hafa kera í gallblöðru eru hins vegar vel skilgreindir. Nefna má fylgikvilla eins og galllífhimnubólgu (biliary peritonitis), endurtekna gallblöðrubólgu, blæðingu (frá lifur eða kviðvegg), loftbrjóst (pneumothorax), ranga legu kera eða að keri rennur út úr gallblöðru fyrr en áætlað er. Alvarlegir fylgikvillar eru tiltölulega sjaldgæfir. Rannsóknir hafa sýnt um 5\% tíðni fylgikvilla sem krefjast einhvers konar inngripa (fylgikvillar af Clavien-Dindo-flokki $\geq 2$ ). ${ }^{4}$

Markmið rannsóknarinnar var að skoða tíðni keraísetningar við bráða gallblöðrubólgu á Landspítala og fylgikvilla peirrar meðferðar.

\section{Efniviður og aðferðir}

Rannsóknin var afturskyggn. Notað var greiningarkerfi Alpjóðaheilbrigðisstofnunarinnar (International Classification of Diseases, ICD-10) og farið í gegnum sjúkraskrár allra fullorðinna sjúklinga (>18 ára) sem fengu gallvegatengdar sjúkdómsgreiningar ( $\mathrm{K}$ 80-85) á Landspítala. Farið var í gegnum sjúkraskrár peirra sjúklinga og pannig fundnir peir sem meðhöndlaðir voru með kera vegna bráðrar gallblöðrubólgu. Rannsóknin náði yfir tímabilið frá 1. janúar 2010 til 31. desember 2016. Upplýsingum sem var safnað úr sjúkraskrám voru meðal annars aldur, kyn, fylgisjúkdómar, blóðpynningarmeðferð, tímalengd einkenna við greiningu, niðurstöður úr blóð- og myndgreiningarrannsóknum, lega og tímalengd kera og fylgikvilla ísetningar kerans.

Tafla I. Yfirlit fylgisjúkdóma og skipting peirra. Flestir sjúklingar voru með fleiri en einn fylgisjúkdóm.

\begin{tabular}{lcc}
\hline & Fjöldi $(\mathrm{n}=76)$ & Hlutfall (\%) \\
\hline Háprýstingur & 54 & 61 \\
\hline Kransæðasjúkdómur & 22 & 25 \\
\hline Heilablóðfall/tímabundin blóðpurrð í heila & 15 & 17 \\
\hline Sykursýki & 11 & 13 \\
\hline Nýrnabilun & 5 & 6 \\
\hline Skorpulifur & 0 & 0 \\
\hline Langvinn lungnateppa & 4 & 5 \\
\hline Krabbamein & 22 & 25 \\
\hline
\end{tabular}

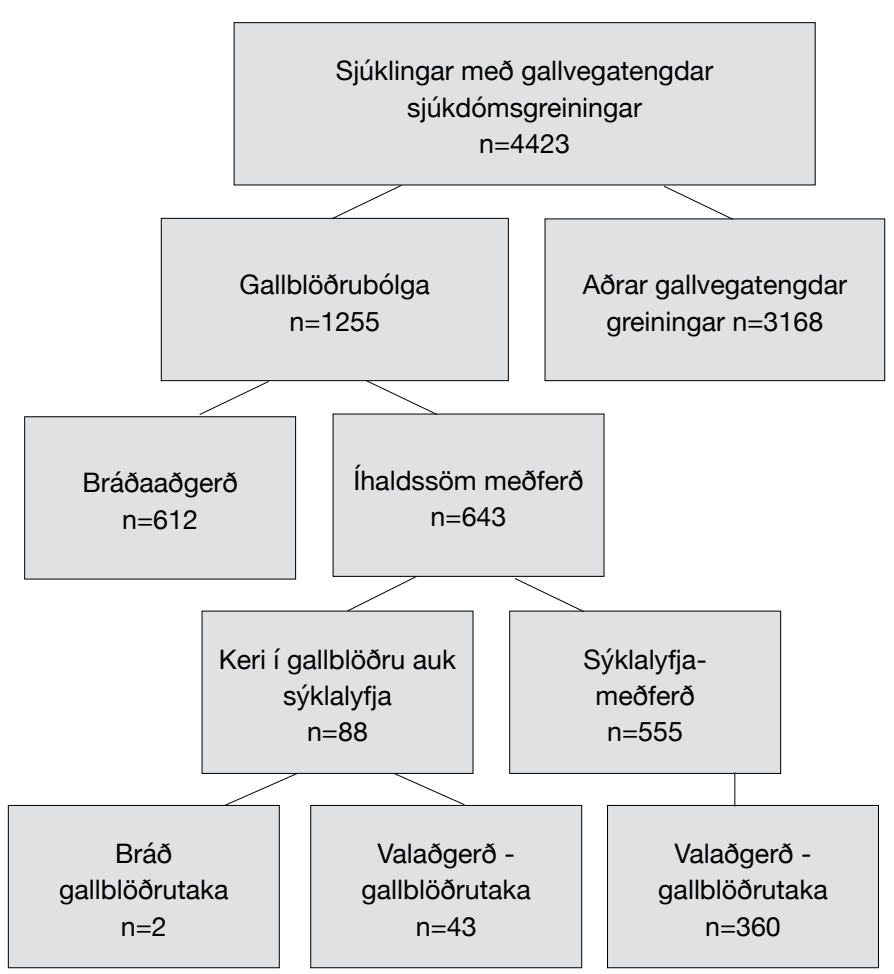

Mynd 1. Flæđirit yfir fjölda sjúklinga á rannsóknartímabilinu og hvađa međferơ peir fengu.

Gallblöðrubólga var skilgreind sem kviðverkur, merki um sýkingu (hiti, hækkun á hvítum blóðkornum og/eða CRP (C-Reactive Protein)) og bólga í gallblöðruvegg, staðfest með myndgreiningu. Sýklasóttarlost (septic shock) var skilgreint sem svæsin sýklasótt ásamt lágum blóðprýstingi eða teikn um minnkað blóðflæði (perfusion) um líffæri. Farið var yfir legu kera í gallblöðru og pegar hún var ekki tekin fram í svari röntgenlæknis fór röntgenlæknir aftur yfir pær myndrannsóknir. Í sumum tilfellum var ekki unnt að staðfesta legu kera út frá myndgreiningargögnum. Fylgikvillar voru flokkaðir samkvæmt Clavien-Dindo-flokkunarkerfinu sem skiptir fylgikvillum niður eftir pví hvort peir krefjist inngripa eða ekki og pá hvers konar inngripa (til dæmis lyfjagjafar, blóðgjafar, innlagnar á gjörgæslu eða skurðaðgerðar). ${ }^{10}$ Dánartíðni var skilgreind sem dauði innan 30 daga frá ísetningu kera. Breytur voru skráðar í Microsoft Excel $^{\circledR}$ sem einnig var notað við úrvinnslu. Notuð var lýsandi tölfræði.

Tilskilin leyfi fengust frá vísindasiðanefnd og framkvæmdastjóra lækninga á Landspítala.

\section{Niðurstöður}

Alls fengu 4423 sjúklingar gallvegatengdar sjúkdómsgreiningar á rannsóknartímabilinu. Par af voru 1255 (28\%) með bráða gallblöðrubólgu og af peim voru konur 700 (56\%). Meðalaldur sjúklinga með gallblöðrubólgu var 58 ár (bil: 18-99). Alls fóru 1018 sjúklingar (81\%) í gallblöðrutöku. Bráðaaðgerð var gerð hjá 612 sjúklingum (49\%) en 643 sjúklingar fengu íhaldssama meðferð með sýklalyfjum og var hluti peirra tekinn til valaðgerðar síðar (63\%). Tveir sjúklingar sem meðhöndlaðir voru í upphafi með íhaldssamri meðferð fóru í bráðaaðgerð í sömu legu (mynd 1). Meðalaldur sjúklinga sem fóru í bráðaaðgerð var 50 ár (bil: 18-88) 


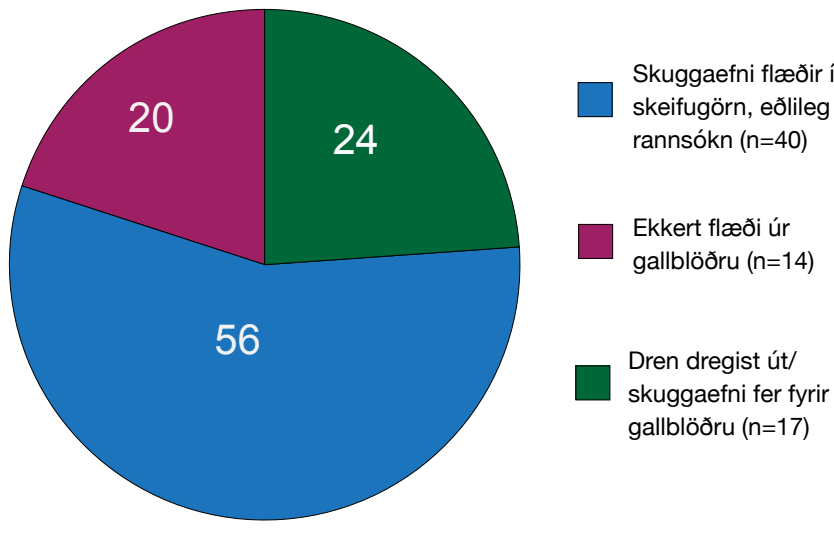

Mynd 2. Skífuritið sýnir niðurstöður úr gallvegamyndatöku sem gerð var um kera $(n=71)$.

og peirra sem fengu íhaldssama meðferð 66 ár (bil: 19-99) og var munurinn marktækur $(\mathrm{p}<0,05)$. Hjá peim sjúklingum sem meðhöndlaðir voru með íhaldssamri meðferð (n=643) var keri lagður í gallblöðru hjá 88 (14\%). Meðalaldur sjúklinga sem fengu kera var 71 ár (bil: 28-92) miðað við 62 ár hjá peim sem ekki fengu kera $(\mathrm{p}<0,05)$ og var hlutfall karla og kvenna jafnt. Sjúklingar sem fengu kera höfðu haft einkenni ( $\mathrm{n}=81)$ að meðaltali í fjóra daga (bil: 0-28) fyrir komu á sjúkrahús, en tímalengd einkenna var óljós hjá 7 sjúklingum. Við greiningu peirra sem meðhöndlaðir voru með kera voru hvít blóðkorn að meðaltali 15,7 x 10\%/L (bil: 2-68,3) og CRP 212 mg/L (bil: 4-524) hjá peim sem meðhöndlaðir voru með kera. Fjórðungur peirra $(\mathrm{n}=22)$ var með einkenni sýklasóttar við greiningu. Meirihluti sjúklinga sem fengu kera höfðu fylgisjúkdóma $(86 \%)$ og voru margir peirra með fleiri en einn (tafla I). Alls höfðu 7 sjúklingar (8\%) sem fengu kera fengið gallblöðrubólgu áður og rúmlega priðjungur sjúklinga (n=33, 38\%) hafði farið áður í aðgerðir á kviðarholi.

Prjátíu og prír sjúklingar (38\%) sem fengu kera í gallblöðru voru á blóðpynningarmeðferð við innlögn. Flestir sjúklinganna voru á warfaríni, eða 17 (52\%), en önnur lyf voru asetýlsalisýlsýra $(n=15,45 \%)$, klópídógrel $(n=1,3 \%)$, rívaroxaban $(n=1,3 \%)$ og enoxaparínnatríum $(\mathrm{n}=1,3 \%)$.

Keri var lagður í gegnum lifur hjá 62 sjúklingum (70\%) en hjá 15 (17\%) fór keri ekki gegnum lifur. Lega á kera var óviss hjá 11 sjúklingum (13\%). Ástungan var gerð ómstýrt hjá 58 sjúklingum (66\%), hjá 16 (18\%) með aðstoð sneiðmyndatækis og hjá 14 (16\%) var notast við hvort tveggja. Keri var fjarlægður fyrir útskrift hjá flestum sjúklinganna eða 71 (81\%) en 17 (19\%) sjúklingar voru útskrifaðir með kera. Áður en keri var fjarlægður var gerð röntgenmyndataka af gallvegum með skuggaefni um kera (secondary cholangiography) hjá 71 sjúklingi (81\%). Niðurstöður gallvegamyndatöku má sjá á mynd 2. Meðaltímalengd kerameðferðar var 12 dagar (miðgildi 7, bil: 0-87), en óvíst var um tímalengd kerameðferðar hjá 5 sjúklingum. Tímalengd kerameðferðar hjá sjúklingum (n=17) sem voru útskrifaðir heim með kera var að meðaltali 39 dagar (miðgildi 44, bil: 6-87) miðað við 7 daga (miðgildi 6, bil: 0-26) hjá sjúklingum par sem keri var fjarlægður inni á sjúkrahúsi $(\mathrm{p}<0,05)$. Hjá tveimur sjúklingum var gerð bráðaaðgerð í legu prátt fyrir kerameðferð. Annar peirra fékk sýklasóttarlost prátt fyrir keraísetningu og var pví tekinn til aðgerðar brátt, sama dag og ástungan var gerð. Hjá hinum dróst keri út og vegna viðvarandi einkenna prátt fyrir íhaldssama meðferð var ákveðið að taka hann til bráðaaðgerðar í sömu sjúkrahúslegu, 26 dögum frá keraísetningu.

Gallblöðrutaka var gerð síðar hjá $43(49 \%)$ af peim 88 sjúklingum sem fengu kera og fór aðgerðin fram að meðaltali 101 degi eftir ísetningu kerans (bil: 30-258). Flestar aðgerðirnar ( $n=41$, 95\%) byrjuðu sem kviðsjáraðgerðir en hjá 5 sjúklingum (12\%) var henni breytt í opna aðgerð. Hjá tveimur sjúklingum var ákveðið að framkvæma opna gallblöðrutöku. Ákvörðun um opna aðgerð var annars vegar vegna gruns um æxli í gallblöðru og hins vegar vegna pess að sjúklingur hafði fengið gallblöðrubólgu tvisvar á stuttum tíma og keri var í gallblöðru án viðkomu í lifur. Meðalaðgerðartími kviðsjáraðgerða $(\mathrm{n}=38)$ var 96 mínútur (bil: 41-227) en opinna aðgerða $(n=5) 123$ mínútur (bil: 93-156) en munurinn var ekki marktækur $(\mathrm{p}=0,29)$.

Upplýsingar um ASA-flokkun (American Society of Anesthesiologists classification) voru skráðar af svæfingalæknum fyrir 42 af peim 45 sjúklingum sem fóru í gallblöðrutöku (93\%). Níu sjúklingar (21\%) voru í ASA-flokki 1, 23 (55\%) í flokki 2 og 10 (24\%) í flokki 3.

Sextíu og einn sjúklingur (69\%) fengu ekki fylgikvilla eftir ísetningu kera en 27 sjúklingar (31\%) fengu alls 28 fylgikvilla. Tuttugu pessara fylgikvilla (63\%) tilheyrðu Clavien-Dindo-flokki I par sem engrar meðferðar er pörf. Algengasti fylgikvillinn var að keri dróst út ( $\mathrm{n}=20,71 \%)$. Tveir sjúklingar $(7 \%)$ purftu nýjan kera og einn (4\%) var tekinn til bráðrar gallblöðrutöku eftir að keri rann út, vegna viðvarandi einkenna. Aðrir fylgikvillar voru verkir vegna kera $(n=3,11 \%)$ sem meðhöndlaðir voru með verkjalyfjum. Prír sjúklingar (11\%) fengu gallleka og purftu tveir peirra bráðaaðgerð vegna galllífhimnubólgu par sem saumað var yfir gatið á gallblöðrunni. Einn sjúklingur fékk íhaldssama meðferð með verkjaog sýklalyfjum. Hjá pessum premur sjúklingum lá keri ekki gegnum lifur. Tveir sjúklingar (7\%) fengu gallblöðrubólgu að nýju eftir að kerameðferð lauk, báðir innan 30 daga frá keraísetningu og eftir útskrift af sjúkrahúsi. Alls létust 5 sjúklingar (6\%) innan 30 daga frá keraísetningu. Tveir létust eftir útskrift af sjúkrahúsi og eftir að meðferð við gallblöðrubólgu var lokið (aldur 76 og 84 ár). Prír sjúklingar (3\%) létust vegna undirliggjandi alvarlegs ástands í tengslum við gallblöðrubólgu og sýklasóttarlost (aldur 80, 84 og 90 ár), par af tveir innan sólarhrings frá keraísetningu.

\section{Umræður}

Mikill fjöldi sjúklinga leggst inn á Landspítala árlega með gallblöðrubólgu og lagðist sjúklingur inn annan hvern dag á pví tímabili sem hér var skoðað. Priðjungur peirra sjúklinga sem fékk gallvegatengdar sjúkdómsgreiningar var með gallblöðrubólgu, sem er í samræmi við aðrar rannsóknir og var meðalaldur peirra einnig sambærilegur fyrri rannsóknum.1,4,11 Meirihluti sjúklinga með gallblöðrubólgu, eða um $80 \%$, fóru í gallblöðrutöku en athygli vekur að einungis helmingur peirra fór í bráðaaðgerð. Pessar niðurstöður eru í samræmi við amerískar og evrópskar rannsóknir. 1,2 Prátt fyrir að skurðaðgerð sé ráðlögð meðferð við bráðri gallblöðrubólgu eru ýmsir pættir sem geta leitt til pess að aðgerð er frestað, eins og tímalengd einkenna, undirliggjandi ástand sjúk- 
lings, aðgengi að skurðstofu og fleira, eins og áður hefur komið fram. ${ }^{12,14}$ Í ljós kom að sá hópur sjúklinga sem var meðhöndlaður með íhaldssamri meðferð var marktækt eldri og líklegt að aldur hafi haft áhrif á ákvarðanatöku um hvort aðgerð var framkvæmd eða ekki.

Um 14\% sjúklinga sem meðhöndlaðir voru með íhaldssamri meðferð fengu kera í gallblöðru og var sá hópur marktækt eldri en peir sem ekki fengu kera. Ekki liggur fyrir samanburður við pá sem fóru í bráðaaðgerð en peir sjúklingar sem fengu kera voru í um 80\% tilfella í ASA-flokki 2 og 3 og um 90\% höfðu fylgisjúkdóma. Pegar eldri rannsóknir eru skoðaðar kemur í ljós að hlutfall peirra sem meðhöndlaðir eru með kera er nokkuð minna en í okkar rannsókn, eða um 4-10\%.4,15,16 Samkvæmt alpjóðlegum leiðbeiningum um meðhöndlun gallblöðrubólgu er mælt með að stiga bólguna meðal annars með myndgreiningu og nota pað til viðmiðunar við meðhöndlun, eins og nú er gert. Hins vegar er mælt með að meðhöndla sjúklinga með kera fyrr en verið hefur ef peir hafa umtalsverða bólgu og er ekki treyst í aðgerð vegna fylgisjúkdóma eða tímalengdar einkenna. ${ }^{2}$ Á Landspítala hafa viðmið úr umræddum leiðbeiningum verið almennt notuð, pað er að framkvæma aðgerð ef sjúklingur er talinn pola hana og tímalengd einkenna er minni en 72 klukkustundir. Í nýrri útgáfu umræddra leiðbeininga er hins vegar talað um að íhuga eigi að framkvæma aðgerð allt upp í 7 dögum eftir upphaf einkenna ef bólga með skoðun og myndgreiningu er talin væg. Í afturskyggnri rannsókn eins og pessari er hins vegar erfitt að meta ástæður fyrir pví að bráđaaðgerð var ekki framkvæmd og líklegt að meðhöndlun með blóðpynningu, fylgikvillar og aðgengi að skurðstofum spili par stórt hlutverk.

Mikilvægt er að gallblöðrukeri sé lagður gegnum lifur ef ekki eru frábendingar fyrir pví, svo sem meðferð með blóðpynningarlyfjum, storkukvillar eða vökvasöfnun í kvið. Lega kerans gegnum lifur hindrar gallleka eftir að keri hefur verið fjarlægður. Petta er pó ekki alltaf tæknilega mögulegt. Petta var gert hjá rúmlega $70 \%$ sjúklinga í pessari rannsókn sem er svipað hlutfall og gerist í erlendum rannsóknum. ${ }^{16-19}$ Hjá 11 sjúklingum var ekki tekið fram hvernig keri var lagður og ekki var hægt að staðfesta legu hans síðar pegar myndrannsóknir voru yfirfarnar. Keri pessara 11 sjúklinga var lagður ómstýrt en erfitt getur verið að túlka ómskoðunarmyndir sem vistaðar eru við rannsókn og pví mikilvægt að petta sé tekið fram í röntgensvari. Hjá premur sjúklingum sem fengu fylgikvilla var keri ekki lagður í gegnum lifur og fengu peir gallleka sem olli lífhimnubólgu hjá tveimur, með peim afleiðingum að peir purftu bráðaaðgerð. petta undirstrikar mikilvægi pess að keri sé lagður í gegnum lifur, séu ekki gildar ástæður til að forðast pað.

Meðalaldur sjúklinga sem fékk kera í bólgna gallblöðru var 71 ár og voru peir marktækt eldri en sjúklingar sem ekki fengu kera. Einkenni sjúklinga höfðu varað að meðaltali í fjóra daga og er pað sambærilegt öðrum rannsóknum..$^{1718,20}$ Röntgenmyndataka um kera er oft gerð til að sjá hvort skuggaefni sem sprautað er um kera flæði úr gallblöðru, niður í gallrás og út í skeifugörn. Ef skuggaefnið flæðir ekki á pennan hátt eða ef steinn er í gallrás (choledochus) eru meiri líkur á að einkenni taki sig upp að nýju. ${ }^{21}$ Tveir sjúklingar fengu endurtekna gallblöðrubólgu eftir að keri var tekinn. Hjá öðrum var ekki gerð gallvegamyndataka um kerann áđur en hann var tekinn. Hjá hinum var sýnt fram á gallrásarstein við gallvegamyndatöku og pví framkvæmd röntgenrannsókn á gallvegum og brisgangi með holsjá (Endoscopic Retrograde Cholangiopancreatography, ERCP). Sá fékk einkenni gallblöðrubólgu innan mánaðar eftir að keri hafði verið fjarlægður og pá meðhöndlaður með sýklalyfjum eingöngu. Priðjungur sjúklinga fékk fylgikvilla af keraísetningunni. Flestir fylgikvillar sem sáust í pessari rannsókn voru af flokki I samkvæmt Clavien-Dindo-flokkunarkerfinu en sá hópur parfnast engrar sérstakrar meðhöndlunar. Algengast var að keri drægist út sem er sambærilegt pví sem aðrar rannsóknir hafa sýnt. ${ }^{8,15,17,22}$ Tveir peirra purftu nýjan kera en einn var tekinn í aðgerð vegna viðvarandi einkenna. Fylgikvillatíðni fyrir flokk II, IV var 29\%. Fimm sjúklingar létust innan 30 daga frá ísetningu kera. Tveir létust á hjúkrunarheimili af öðrum ástæðum, á hjúkrunarheimili eftir að meðferð við gallblöðrubólgu lauk. Prír sjúklingar létust hins vegar vegna sýklasóttar sem varð ekki snúið við prátt fyrir meðhöndlun með kera en ekki af beinum fylgikvillum við keraísetninguna og eru pví ekki teknir inn í fjölda sjúklinga með fylgikvilla keraísetningar. Pessir prír sjúklingar voru meðhöndlaðir á gjörgæslu og var ekki treyst í aðgerð vegna undirliggjandi ástands og var kera komið fyrir í peirri von að hægt væri að snúa við ástandi sýklasóttarlosts. Samkvæmt pessu er 30 daga dánartíðni 6\% sem er sambærilegt við aðrar rannsóknir sem hafa sýnt fram á dánartíðni á bilinu 5-20\% hjá sjúklingum sem fá kera sem meðferð við gallblöðrubólgu. ${ }^{14,17-19}$ Líkt og í okkar rannsókn hefur dánartíðnin í pessum rannsóknum verið rakin til alvarleika gallblöðrubólgunnar frekar en að tengjast ísetningu kera. ${ }^{12}$

Tilgangur rannsóknarinnar var að skoða tíðni á notkun kera í gallblöðru við bráðri gallblöðrubólgu og fylgikvillum peirrar meðferðar. Óhætt er að segja að tíðni á notkun kera er lág en möguleiki á að hún aukist á næstu árum í samræmi við nýlegar leiðbeiningar. ${ }^{2}$ Fylgikvillatíðni er einnig lág hér á landi. Helsti styrkur pessarar rannsóknar er að hún tekur til allra sjúklinga sem meðhöndlaðir voru með kera í gallblöðru við gallblöðrubólgu á Landspítala á 7 ára tímabili. Helsti annmarki rannsóknarinnar er að hún er afturskyggn og að upplýsingar um til dæmis ákvörðun meðferðar og sjúkrasögu pví ekki eins nákvæmar og verið hefði í framskyggnri rannsókn. Höfundar telja pví pörf á framskyggnri rannsókn á sjúklingum með bráða gallblöðrubólgu. Pá væri meðal annars hægt að skoða ástæður fyrir ákvörðun um meðferð, aðgerð eða íhaldssama meðferð, og meta áhrif á einkenni sjúklings. 


\section{Heimildir}

1. Pålsson S, Saliba G, Sandblom G. Outcome after cholecystectomy in the elderly: A population-based register study. Scand J Gastroenterol 2016; 51: 974-8.

2. Mayumi T, Okamoto K, Takada T, Strasberg SM, Solomkin JS, Schlossberg D, et al. Tokyo guidelines 2018: management bundles for acute cholangitis and cholecystitis. J Hepatobiliary Pancreat Sci 2018; 25:9 6-100.

3. Genc V, Sulaimanov M, Cipe G, Basceken SI, Erverdi $\mathrm{N}$, Gurel $\mathrm{M}$, et al. What necessitates the conversion to open cholecystectomy? A retrospective analysis of 5164 consecutive laparoscopic operations. Clinics (Sao Paulo) 2011; 66: 417-20.

4. Popowicz A, Lundell L, Gerber P, Gustafsson U, Pieniowski E, Sinabulya $\mathrm{H}$, et al. Cholecystostomy as bridge to surgery and as definitive treatment or acute cholecystectomy in patients with acute cholecystitis. Gastroenterol Res Pract 2016; 2016: 3672416.

5. Riall T, Zhang D, Townsend CJ, Kuo Y, Goodwin J. Failure to perform cholecystectomy for acute cholecystitis in elderly patients is associated with increased morbidity, mortality, and cos. J Am Coll Surg 2010; 210: 10.

6. Nasim S, Khan S, Alvi R, Chaudhary M. Emerging indications for percutaneous cholecystostomy for the management of acute cholecystitis--a retrospective review. Int J Surg 2011; 9: 456-9.
7. Ni Q, Chen D, Xu R, Shang D. The efficacy of percutaneous transhepatic gallbladder drainage on acute cholecystitis in high-risk elderly patients based on the tokyo guidelines: A retrospective case-control study. Medicine 2015; 94: e1442.

8. Stanek A, Dohan A, Barkun J, Barkun A, Reinhold C, Valenti D, et al. Percutaneous cholecystostomy: A simple bridge to surgery or an alternative option for the management of acute cholecystitis? Am J Surg 2018

9. Berman M, Nudelman IL, Fuko Z, Madhala O, NeumanLevin M, Lelcuk S. Percutaneous transhepatic cholecystostomy: Effective treatment of acute cholecystitis in high risk patients. Isr Med Assoc J 2002; 4: 331-3.

10. Dindo D, Demartines N, Clavien PA. Classification of surgical complications: A new proposal with evaluation in a cohort of 6336 patients and results of a survey. Ann Surg 2004: 240: 205-13.

11. Halpin V. Acute cholecystitis. BMJ Clin Evid 2014; 2014

12. Melloul E, Denys A, Demartines N, Calmes JM, Schäfe M. Percutaneous drainage versus emergency cholecystectomy for the treatment of acute cholecystitis in critically ill patients: Does it matter? World J Surg 2011; 35: 826-33.

13. Grant A, Neuberger J. Guidelines on the use of liver biopsy in clinical practice. British society of gastroenterology. Gut 1999; 45 Suppl 4: IV1-IV11.

14. Pang KW, Tan $\mathrm{CH}$, Loh S, Chang KY, Iyer SG, Madhavan $\mathrm{K}$, et al. Outcomes of percutaneous cholecystostomy for acute cholecystitis. World J Surg 2016; 40: 2735-44.
15. Cooper S, Donovan M, Grieve DA. Outcomes of percutaneous cholecystostomy and predictors of subsequent cholecystectomy. ANZ J Surg 2017.

16. Chang YR, Ahn YJ, Jang JY, Kang MJ, Kwon W, Jung WH, et al. Percutaneous cholecystostomy for acute cholecystitis in patients with high comorbidity and re-evaluation of treatment efficacy. Surgery 2014; 155: 615-22.

17. Horn T, Christensen S, Kirkegård J, Larsen L, Knudsen A, Mortensen F. Percutaneous cholecystostomy is an effective treatment option for acute calculous cholecystitis: a 10-year experience. HPB (Oxford) 2015; 17: 326-31.

18. Bundy J, Srinivasa RN, Gemmete JJ, Shields JJ, Chick JFB. Percutaneous Cholecystostomy: Long-Term Outcomes in 324 Patients. Cardiovasc Intervent Radiol 2018; 41: 928-34.

19. Polistina F, Mazzucco C, Coco D, Frego M. Percutaneous cholecystostomy for severe (Tokyo 2013 stage III) acute cholecystitis. Eur J Trauma Emerg Surg 2018.

20. Kamer E, Cengiz F, Cakir V, Balli O, Acar T, Peskersoy $\mathrm{M}$, et al. Percutaneous cholecystostomy for delayed laparoscopic cholecystectomy in patients with acute cholecystitis: analysis of a single-centre experience and literature review. Prz Gastroenterology 2017; 12: 250-5.

21. Gulaya K, Desai SS, Sato K. Percutaneous cholecystostomy: Evidence-based current clinical practice. Semin Intervent Radiol 2016; 33: 291-6.

22. Viste A, Jensen D, Angelsen JH, Hoem D. Percutaneous cholecystostomy in acute cholecystitis; a retrospective analysis of a large series of 104 patients. BMC Surg 2015 15: 17

\section{Percutaneous cholecystostomy as treatment for acute cholecystitis at Landspitali University Hospital 2010 - 2016}

\section{Katrín Hjaltadóttir \\ Kristín Huld Haraldsdóttir \\ Pétur Hörður Hannesson \\ Páll Helgi Möller}

Introduction: Acute cholecystitis is one of the most common reasons for acute admission in abdominal surgery. The recommended therapy is cholecystectomy but occasionally that is not possible and a conservative treatment with intravenous antibiotics is used. Should the patient not respond to conservative treatment a percutaneous catheter can be placed in the gallbladder (cholecystostomy). The aim of the study was to look at the frequency of which cholecystostomies were used and the complication rates at Landspitali, The National University Hospital of Iceland.

Materials and methods: $A$ retrospective study where patient charts of those with ICD - diagnosis numbers K80 - 85 at Landspitali University Hospital looked at and patients who received cholecystostomies were identified in the period from 2010 - 2016. Clinical information was registered in Excel. Descriptive statistics were used.
Results: A total of 4423 patients were diagnosed with biliary disease during the study period. 1255 (28\%) of them had acute cholecystitis with mean age of 58 years (range: $18-99$ ). A cholecystostomy was put in 88 patients (14\%), mean age 71 years (range: 28 - 92). A transhepatic route was used for $62(70 \%)$ and the drain was in place for an average of 12 days (range: 0 - 87). A secondary cholangiography was performed in 71 cases. Seventeen patients were discharged home with the cholecystostomy in place. Half of the patients underwent a laparoscopic cholecystectomy 101 days from drain insertion (range: 30 - 258). A total of 28 complications were noted in 27 patients (31\%) and the most common complication was dislodgement of the catheter $(n=20)$. Five patients $(6 \%)$ died within thirty days of the intervention, three from septic shock and two from reasons unrelated to the treatment.

Conclusions: Cholecystostomy is not a common choice of treatment for acute cholecystitis at Landspitali, The National University Hospital of Iceland. Few serious complications arise from the treatment and no patients died in relation to the intervention. 